\title{
Lipase Activity of Endophytic Actinobacteria from Medicinal Plants
}

\author{
Yulin Lestari'1,3*, Budi Wirawan', Sri Budiarti', Min Rahminiwati ${ }^{2,3}$ \\ ${ }^{1}$ Department of Biology, Faculty of Mathematics and Natural Sciences, Bogor Agricultural University, Bogor, Indonesia \\ ${ }^{2}$ Department of Anatomy, Physiology and Pharmacology, Faculty of Veterinary Medicine, Bogor Agricultural University, Bogor, Indonesia \\ ${ }^{3}$ Tropical Biopharmaca Research Center, Institute of Research and Community Empowerment, Bogor Agricultural University, \\ Bogor, Indonesia
}

\section{ARTICLE INFO}

\section{Article history:}

Received November 29, 2017

Received in revised form December 20, 2017

Accepted January 15, 2018

\section{KEYWORDS:}

Curcuma xanthorrhiza, endophytic bacteria,

Guazuma ulmifolia,

lipase,

Psidium guajava

\begin{abstract}
Endophytic bacteria are known to reside within host plant tissue without giving a harmfull effect. The endophytes may play an important role, as they may produce similar bioactive compounds as produced by the host plant. Various medicinal plants have long been used to cure diseases. Traditionally, leaves extract of Guazuma ulmifolia, Psidium guajava, or the rhizome of Curcuma xanthorrhiza can be used to treat disease, e.g. hyperlipidemic. The mechanism can be through lipase activity, where the lipase catalyzes the hydrolysis of triacylglycerol to fatty acids and acylglycerol. The objective of this research was to assess potency of endophytic bacteria as anti-hyperlipidemic compounds producer through their lipase activity. Sixty nine endophytic bacteria which comprised of 22, 27 and 20 isolates were isolated from the leaves of $G$. ulmifolia, $P$. guajava, and the rhizome of $C$. xanthorrhiza, respectively. Eight out of the 69 isolates showed lipase activity, and the two selected isolates, i.e. DPG 3(2) and AJB 4(4) were considered as good lipase producers. The highest specific lipase activity of DPG 3(2) isolate was observed for 0.874 units per $\mathrm{mg}$ at $38 \mathrm{~h}$, whereas AJB 4(4) isolates had the specific lipase activity at 1.139 units per $\mathrm{mg}$ after $72 \mathrm{~h}$ observation. These data indicate that the two selected isolates have the potency as antihyperlipidemic compounds producer through their lipase activity.
\end{abstract}

\section{Introduction}

Changing in lifestyle can lead to a shift in food consumption patterns to products that contain more fat and less fiber, which can cause the problem of obesity. Overweight refers to a situation of excess weight due to increase concentrations of blood lipids which characterised by the increasing of triglycerides, low density lipoprotein (LDL), total cholesterol in the blood exceed normal limits ( $>200 \mathrm{mg} / \mathrm{dL}$ ), and decreasing concentrations of high density lipoprotein (HDL) $(<40 \mathrm{mg} / \mathrm{dL})$ (Forti and Diament 2006). This condition is known as hyperlipidemic, which can trigger the emergence of various diseases such as atherosclerosis, which is a cause of coronary heart disease (CHD) and stroke. Hyperlipidemic can be caused by changes in diet, like consuming a lot of fat, especially saturated fat, sugar, alcohol, salt in the daily diet, lack of exercise, genetic disorders, emotional stress, and metabolic disorders. Some conventional

\footnotetext{
* Corresponding Author

E-mail Address: yulinlestari@gmail.com
}

way to solve the problem of hyperlipidemic is by doing physical exercise, low cholesterol diet and consuming antiobesity drugs. Alternatively, person with obesity can use of natural ingredients such as medicinal plant extract to reduce the concentration of fat in the body.

Several medicinal plants, e.g. leaves extracts of G. Ulmifolia, P. guajava, and the extract of rhizome of $C$. xanthorrhiza, traditionally and empirically can be used to lower the lipid concentration of obesity person. Some research data indicated that giving the plant extracts could decrease the concentration of cholesterol in hyperlipidemic mouse liver (Rahayu 2007). Several bioactive compounds produced by endophytic bacteria can function as antitumor, antiinflammatory, antioxidant (Firaikovai et al. 2007), antimicrobes and enzyme inhibitor (Lestari 2006; Pujiyanto et al. 2012; Lestari et al. 2015). The ethanol extract of G. ulmifolia leaves, has the ability as an anti-obesity compound through the mechanism of pancreatic lipase inhibitory activity (Silitonga 2008). Lipase (triacylglycerol hydrolase, EC 3.1.1.3) can hydrolyze triacylgyserol compounds into fatty acids and acylglyserol (Litthauer et al. 2002). 
Various commercial antihyperlipidemic can be chemically synthesized, e.g. amphetamines, phenylpropanolamine, fenflur-amine and dexfenfluramine; or naturally it can be produced by Streptomyces toxytricini, e.g. lipstatin that works as an inhibitor of pancreatic lipase enzyme (Weibel et al. 1987). Antihyperlipidemic commercial product is known as Orlistat (tetrahydrolipstatin, Xenical ${ }^{\circledR}$ ), and another relatively new antihyperlipidemic compounds is known from the bioconversion of compound FR177391 by Serratia liquefaciens (Kobayashi et al. 2005). These data indicate that the microbes are able to produce bioactive compounds that can serve as antihyperlipidemic.

Endophytic bacteria that colonize plant tissues play an important role, and may produce similar bioactive compounds as produced by the host plant. The endophytes obtain nutrients and protection from the host plant. The role of endophytes of medicinal plants which traditionally used for lowering cholesterol, thus it can function as antihyperlipidemic is rarely reported. Scientific data about antihyperlipidemic compound still limited to the properties contained within the plant, while the antihyperlipidemic compound produced by endophytic microbes is rarely explored. This work aimed to asses lipase activity of endophytic bacteria from several medicinal plants with traditionally used as antihyperlipidemic. The results from this study contributes to the deeping understanding regarding the potency of endophytic bacteria from medicinal plants which has antihyperlipidemic activity.

\section{Materials and Methods}

\subsection{Screening of Lipase Activity of Endophytic Bacteria}

There were sixty nine of endophytic bacteria belonged to actinobacteria and non-actinobacteria isolated from medicinal plants were assesed for their lipase activity. The non actinobacteria was innoculated ( $0.8 \mathrm{~cm}$ in diameter of innoculum) on Triton Glucose Yeast Extract (TGY) medium containing (per L): $5 \mathrm{~g}$ tryptone, 5 g yeast extract, $1 \mathrm{~g}$ dextrose, and $1 \mathrm{~g} \mathrm{~K}_{2} \mathrm{HPO}_{4}$ at $\mathrm{pH}$ 7.2, whereas the actinobacteria were inoculated on to International Streptomyces Project no. 2 (ISP2) media. Each of those media supplemented with $3 \%$ of olive oil and $2 \mathrm{~mL}$ of $0.1 \%$ Rhodamine B dye that has been sterilized using millipore (Swinnex) $0.2 \mu \mathrm{m}$. The non actinobacteria were incubated at $30^{\circ} \mathrm{C}$ for 2 days, while the actinobacteria were incubated at $25^{\circ} \mathrm{C}$ for 5 days. Lipase activity in the screening media was detected under UV light as fluorescent orange zone.

\subsection{Pattern of Lipase Activity}

The selected isolates that have high lipase activity were inoculated in to $50 \mathrm{~mL}$ Tryptone Soy Broth (TSB) media, and incubated at $50^{\circ} \mathrm{C}$ for 24 hours. The bacterial starter culture were then inoculated in to $50 \mathrm{~mL}$ of production medium (per $\mathrm{L}$ ) contained 1\% olive oil, $0.02 \% \mathrm{CaCl}_{2} \cdot 2 \mathrm{H}_{2} \mathrm{O}, 0.01 \% \mathrm{MgSO}_{4} \cdot 7 \mathrm{H}_{2} \mathrm{O}$, and $0.04 \% \mathrm{FeCl}_{3} \cdot 6 \mathrm{H}_{2} \mathrm{O}$. The non actinobacterial culture was incubated at $50^{\circ} \mathrm{C}$ in a shaker incubator of 150 rpm. Every 12 hours, bacterial sample was collected to measure cell density using $620 \mathrm{~nm}$ wave length, which lasted for 4 days. Meanwhile, the actinobacterial culture was taken every 24 hours for 10 days. The cell culture was centrifuged for $10 \mathrm{~min}$ at $4^{\circ} \mathrm{C}, 10000 \mathrm{rpm}$ to separate cell biomass and supernatant. The obtained supernatant was treated as crude extract containing lipase and then measured for its lipase activity.

\subsection{Lipase Activity and Protein Content}

The crude extract containing enzyme was measured for its lipase activity using the method of Kwon and Rhee (1986). One mL of sample was mixed into a solution containing $2.5 \mathrm{~mL}$ of olive oil, $0.005 \mathrm{M}$ phosphate buffer (1: 1), and $20 \mathrm{~mL} \mathrm{CaCl}_{2}$. The solution was placed in a shaker incubator, $200 \mathrm{rpm}$ at $60^{\circ} \mathrm{C}$ for $30 \mathrm{~min}$. Then adding $1 \mathrm{~mL}$ of $6 \mathrm{~N} \mathrm{HCl}$ and $5 \mathrm{~mL}$ iso-octane, followed by homogenizing using a vortex for $1 \mathrm{~min}$.

Four $\mathrm{mL}$ of top layer of iso-octan was transferred into a new tube, and added with $1 \mathrm{~mL}$ cupric acetatepyridine reagent,then homogenized using a vortex for $1 \mathrm{~min}$. After that the mixed solution was measured for its absorbance using a spectrophotometer at $715 \mathrm{~nm}$ wavelength. One unit of lipase activity was defined as the amount of enzyme that release $1 \mathrm{~mol}$ of fatty acids per $\mathrm{mL} / \mathrm{min}$ at $60^{\circ} \mathrm{C}$. Measurement of lipase activity was done by using margaric acid (heptadecanoic acid), as standard curve, measured the absorbance at 715 $\mathrm{nm}$.

Margaric acid is one type of saturated fatty acid, as a result of hydrolysis of triglycerides by lipase enzyme. Margaric acid is also reacted with cupric acetatepyridine reagents. The amount of lipase activity characterized by the number of fatty acid released per minute. Therefore, the use of margaric acid in this study was aimed to measure the approximate amount of fatty acids released from the hydrolysis of triglycerides (olive oil) by the crude extract containing lipase (sample). The protein content was measured by the method of Bradford (1976) using the standard bovine serum albumin (BSA). 


\subsection{Measuring of Specific Lipase Activity}

The specific lipase activity was measured by using the following formula:

$$
\text { Lipase Specific activity (units } / \mathrm{mg})=\frac{\text { lipase activity }(\text { units } / \mathrm{ml})}{\begin{array}{c}
\text { protein content } \\
(\mathrm{ml} / \mathrm{mg})
\end{array}}
$$

The specific lipase activity were then synchronized with the concentration (ppm) of lipase type VII as a positive control.

\section{Results}

\subsection{Lipase Inhibitory Activity of Endophytic Bacteria}

Eight out of 69isolates of endophytic bacteria showed lipase activity indicating by orange luminescence zone on agar medium containing Rhodamine $\mathrm{B}$.

Two selected isolates e.g. DPG 3 (2) and AJB 4 (4) produced strong orange luminescence zone, indicating high lipase activity (Figure 1). The DPG 3 (2), a non actinobacteria, was isolated from leaves of $P$. guajava, while AJB 4 (4), an actinobacteria, was isolated from the roots of G. ulmifolia.

\subsection{Pattern of Lipase Inhibitory Activity}

The highest specific lipase activity produced by DPG 3 (2) was obtained after $36 \mathrm{~h}$ incubation, which was equal to $4.405 \log \mathrm{cfu}$. At that stage, it produced about 0.874 units per $\mathrm{mg}$ of specific lipase activity (Figure 2). At $48 \mathrm{~h}$ measurement and after, the cell number was slightly decreased, in line with slightly decrease in specific lipase activity.

For AJB 4(4), the highest specific lipase activity was obtained at $72 \mathrm{~h}$ incubation that was 1.139 units per $\mathrm{mg}$, after that the specific activity declined (Figure 3 ).
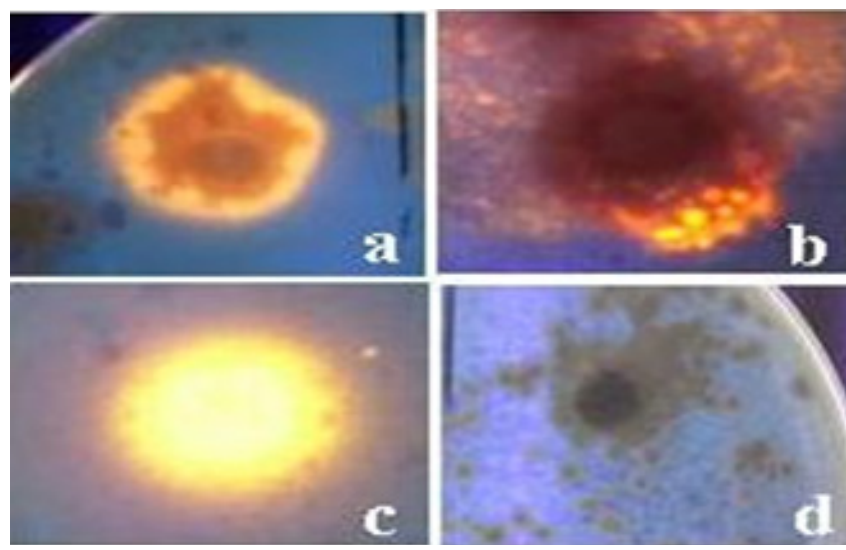

Figure 1. Lipase activity of DPG 3(2) (a), AJB 4(4) (b) grown in screening Rhodamine B media, compared with a positive control, type VII lipase (1000 ppm) (c), meanwhile the AJB 4(3) (d) showing no lipase activity
The specific lipase activity of both DPG 3 (2) and AJB 4 (4) was compared with the concentration of lipase type VII (Sigma chemical Co.), as the positive control.

As shown in Tables 1 and 2, the highest specific lipase activity of DPG 3 (2) was equivalent to 172

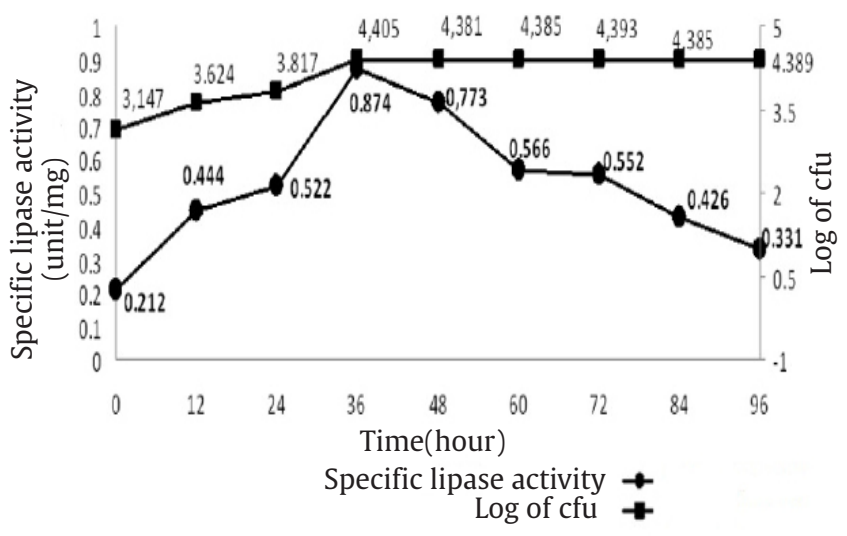

Figure 2. Pattern of specific lipase activity of DPG 3(2) in the medium containing $1 \%$ of olive oil

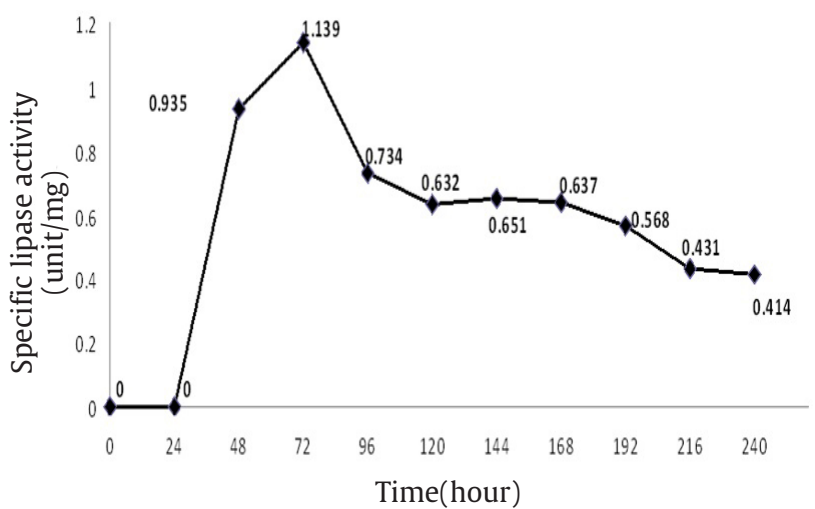

Figure 3. Specific lipase activity of AJB 4(4) in the medium containing $1 \%$ of olive oil

Table 1. Comparation of specific lipase activity of DPG 3(2) with the lipase type VII concentration

\begin{tabular}{ccc}
\hline Time (hour) & $\begin{array}{c}\text { Specific lipase } \\
\text { activity (unit/mg) }\end{array}$ & $\begin{array}{c}\text { Concentration of lipase } \\
\text { type VII (ppm) }\end{array}$ \\
\hline 0 & 0.212 & 2.479 \\
12 & 0.444 & 5.177 \\
24 & 0.522 & 6.080 \\
36 & 0.874 & 10.172 \\
48 & 0.773 & 8.995 \\
60 & 0.566 & 6.592 \\
72 & 0.552 & 6.434 \\
84 & 0.426 & 4.970 \\
96 & 0.331 & 3.826 \\
\hline
\end{tabular}


Table 2. Comparation of specific lipase activity of AJB 4(4) with the lipase type VII concentration

\begin{tabular}{ccc}
\hline Time (hour) & $\begin{array}{c}\text { Specific lipase } \\
\text { activity (unit/mg) }\end{array}$ & $\begin{array}{c}\text { Concentration of lipase } \\
\text { type VII (ppm) }\end{array}$ \\
\hline 0 & 0 & 0 \\
24 & 0 & 0 \\
48 & 0.935 & 10.888 \\
72 & 1.139 & 13.260 \\
96 & 0.734 & 8.552 \\
120 & 0.632 & 7.363 \\
144 & 0.651 & 7.577 \\
168 & 0.637 & 7.415 \\
192 & 0.568 & 6.616 \\
216 & 0.431 & 5.022 \\
240 & 0.414 & 4.823 \\
\hline
\end{tabular}

ppm the concentration of lipase type VII; meanwhile for the AJB 4 (4) was equivalent to $13.260 \mathrm{ppm}$ the concentration of lipase type VII.

\section{Discussion}

Screening of lipase-producing bacteria on an agar medium is usually done by using tributyrin or Tween 80 as the substrate. However, such substrates are not suitable for detecting the actual lipase because the compound can also be hydrolyzed by esterase (Peled and Krenz 1981). Lipase also plays a role in the metabolism of lipoproteins in the blood by hydrolyzing triglycerides and phospholipids contained in chylomicrons, intermediate density lipoprotein (IDL) and HDL(Dugi et al. 2000). Lipase can be visualized on agar containing trioleoylglyserol and a fluorescent Rhodamine B dye (Hofelmann et al. 1983). In this study, $3 \%$ of olive oil was used to substitute the trioleoylgliserol. Eight of the 69 isolates isolation results are already known to have lipase activity in the screening media containing 3\% of olive oil and Rhodamine B dye.

Rhodamine $B$ bind specifically with fatty acids and mono- or diglycerides, this process is highly sensitive. The formation of complexes between Rhodamine B dimer fatty acids and mono- or diglycerides, thus produce luminescence that can be detected under UV light (Kouker and Jaeger 1987). The specificity of this method is shown when esterase is tested on screening media containing $3 \%$ olive oil and Rhodamine B dye, no fluorescent zones generated. The sensitivity of this method has been proven by the fact that the lipase activity can be detected up to 60 nmol of fatty acid released per minute. Meanwhile, screening for lipase activity using titrimetric method can detect lipase activity when reaching $1200 \mathrm{nmol}$ of fatty acids released per minute. Based on that evidences, the eight endophytic bacterial colonies
( 2 isolates of actinobacteria and 6 isolates belonged to non actinobacteria) that have been grown in a medium containing $1 \%$ olive oil and Rhodamine $B$ dye can be confirmed that those isolates able to produce lipase. Both DPG 3(2) and AJB 4(4) showed to produce strong fluorescence orange zone compared with the other six tested isolates. The strength of orange fluorescence can indicate the more capable of the bacteria in producing lipase (Hou and Johnston 1992).

The DPG 3 (2) is a non actinobacteria bacteria, that can secrete proteins with lipase activity in the production media added with $1 \%$ of olive oil. Similarly, Bacillus sp. 42 strain also has a lipase activity in the media containing $1 \%$ olive oil (Eltaweel et al. 2005). The highest specific lipase activity of DPG 3 (2) obtained at the later stage of log phase, when cell density reached the highest number (4.405 $\log$ of $\mathrm{cfu}$ ) at $36 \mathrm{~h}$ incubation and the lipase activity equal to 0.874 units per $\mathrm{mg}$. It has been reported that indigenous Streptomyces sp. SKK1-8 was able to produce xylanase (Meryandini et al. 2006). Some isolates of Streptomyces are also known to produce hydrolytic enzymes such as cellulases, hemicellulase, chitinase, amylase, and glucanase (Hasegawa et al. 2006).

The AJB 4 (4) produced the highest specific lipase activity after incubated for $72 \mathrm{~h}$ which its lipase activity equal to 1.139 units per $\mathrm{mg}$. The specific lipase activity value of both DPG 3 (2) and AJB 4 (4) is positively correlated with various concentrations of lipase type VII used as a positive control. It showed from the highest specific lipase activity value of DPG 3 (2) after $36 \mathrm{~h}$ incubation is equivalent to $10.172 \mathrm{ppm}$ lipase type VII. Similarly, the highest specific lipase activity of AJB 4 (4) reached after 72 h incubation, which was equivalent to 13.260 ppm lipase type VII. Endophytic bacteria from G. ulmifolia and P. guajava can be further studied for their lipase activity such as its roles in lipolysis of reserved fat that accumulate in adipose tissue, thus can effectively cause weight loss.

\section{Conflict of Interest}

The authors declares that there is no conflict of interest.

\section{Acknowledgements}

We gratefully thanks to Division of Microbiology, Department of Biology, Bogor Agricultural University, and Tropical Biopharmaca Research Center for supporting facilities. 


\section{References}

Bradford MM. 1976. A rapid and sensitive method for the quantification of microgram quantities of protein utilizing the principle of protein dye binding. Anal Biochem 72:248-254.

Dugi KA et al. 2000. In vivo evidence for both lipolytic and nonlipolytic function of hepatic lipase in the metablism of HDL. Arterioscler Thromb Vasc Biol 20:793-800.

Eltaweel MA et al. 2005. An organic solvent-stable lipase from Bacillus sp. strain 42. Annals of Microbiol 55:187-192.

Firáikovái S et al. 2007. Bioactive secondary metabolites produced by microorganisms assosiated with plants. Slovakia: Department of Biochemical Technology, Institute of Biotechnology and Food Industry, Slovak University of Technology.

Forti N, Diament J. 2006. High-density lipoproteins: metabolic, clinical, epidemiological and therapeutic inter-vention aspects. An update for clinicians. Arq Bras Cardiol 87:1590-1612.

Hasegawa S et al. 2006. Endophytic actinobacteria and their interaction with host plants. Actinomycetologica 20:72-81.

Hofelman M et al. 1983. Ultra thin-layer agar gels: a novel print technique for ultra thin-layer isoelectric focusing of enzymes. Anal Biochem 128:271-222.

Hou CT, Johnston TM. 1992. Screening of lipase activities with cultures from the agricultural research service culture collection. JAOCS 69:1088-1097.

Kobayashi M et al. 2005. FR177391, a new antihyperlipidemic agent from Serratia. J Antibiot 58:648-653.

Kouker G, Jaeger KE. 1987. Specific and sensitive plate assay for bacterial lipases. Appl Environ Microbiol 53:211213.
Kwon YD, Rhee JS. 1986. A simple and rapid colorimetric method for determination of free fatty acids for lipase assay. JAOCS 63:89-92.

Lestari Y. 2006. Identification of indigenous Streptomyces spp. producing antibacterial compounds.J Mikrobiol Indones 11:99-101.

Lestari Y et al. 2015. Metabolites activity of endophytic Streptomyces sp. IPBCC.b.15.1539 from Tinospora crispa L. Mers: -glucosidase inhibitor and antihyperglycemic in mice. Int J Pharm Pharm Sci 7:235239.

Litthauer D et al. 2002. Pseudomonas luteola lipase: a new member of the 230-residue Pseudomonas lipase family. Enzyme Microb Tech 30:219-226.

Meryandini A et al. 2006. Characterization of xylanase Streptomyces spp. SKK1-8. Hayati 13:151-155.

Peled N, Krenz MC. 1981. A new assay of microbial lipases with emulsified trioleoyl glycerol. Anal Biochem 112:219-222.

Pujiyanto S et al. 2012. Alpha-glucosidase inhibitor activity and characterization of endophytic actinomycetes isolated from some Indonesian diabetic medicinal plants. Int J Pharm Pharm Sci 4:327-333.

Rahayu YS. 2007. Khasiat ekstrak ramuan daun jati belanda terhadap konsentrasi kolesterol hati tikus yang hyperlipidemia [Skripsi]. Bogor: Program Studi Biokimia, Departemen Kimia FMIPA IPB.

Silitonga RF. 2008. Daya inhibisi ekstrak daun jati belanda dan bangle terhadap aktivitas lipase pankreas sebagai anti-obesitas [Skripsi]. Bogor: Program Studi Kimia, Departemen Kimia FMIPA IPB.

Weibel EK et al. 1987. Lipstatin, an inhibitor of pancreatic lipase, produce by Streptomyces toxytricini producing organism, fermentation, isolation and biological activity. J Antibiot 40:1081-1085. 